\title{
Hong Kong Public Social Communication Strategies in a Demonstration Against the Proposed Extradition Law
}

\author{
Rico, Siti Fatimah, Muzahid Akbar Hayat \\ Islamic University Kalimantan Syekh Muhammad Arsyad Al Banjari, Jl. Adhyaksa No.2 Kayu \\ Tangi Banjarmasin, South Kalimantan, 70123, Indonesia \\ Email: ricoaje.1994@gmail.com, ricobdj22@gmail.com and m.akbarhayat@gmail.com
}

\begin{tabular}{|c|c|}
\hline JFO & BSTRACT \\
\hline $\begin{array}{l}\text { Date received : } 04 \text { December } \\
2020 \\
\text { Revision date : } 05 \text { February } \\
2021 \\
\text { Date received : } 02 \text { May } 2021 \\
\text { Keywords: } \\
\text { demosntrasion } \\
\text { extradition bill } \\
\text { social communicaton } \\
\text { autonomy } \\
\text { politics } \\
\text { government }\end{array}$ & $\begin{array}{l}\text { Hong Kong, one of the global financial centers, was plunged } \\
\text { into chaos for almost two months straight from June to July } \\
2019 \text {. For eight weeks, demonstrations by the Hong Kong } \\
\text { people have been going on and on until they become violent. } \\
\text { The demonstration was intended to deny the proposed } \\
\text { extradition law, which would allow Hong Kong prisoners, } \\
\text { including foreigners, to be extradited to China. The extradition } \\
\text { bill is also called to threaten the freedom of local people, to } \\
\text { threaten democracy and law in the Hong Kong region. The } \\
\text { different political systems between China and Hong Kong make } \\
\text { the relationship both vulnerable. As a special region in China, } \\
\text { Hong Kong needs to get the attention of the Chinese } \\
\text { government by conceding its rights and upholding its systems } \\
\text { so that demonstrations need not be too worried. Hong Kong } \\
\text { people are making a variety of attempts at demonstration and } \\
\text { even some social communication strategies are used to reject } \\
\text { the traditional bill. The method used in this study is qualitative } \\
\text { deskriftive with case studies of direct observation of sites and } \\
\text { several demonstration articles in Hong Kong. As a result of this } \\
\text { study, several unique strategies of Hong Kong's } \\
\text { demonstrations have been carried out to maintain a message } \\
\text { being delivered by another group that the Hong Kong } \\
\text { government has even brought attention to the world. }\end{array}$ \\
\hline
\end{tabular}

\section{INTRODUCTION}

The Hong Kong protest events have been happening since early June 2019. It all began with the Hong Kong government's decision that prompted an amendment to the extradition law. One of the desired points of change is to allow extradition from Hong Kong to any non-binding jurisdiction, including mainland China. Hong Kong is part of China's territory, but it has the privilege of one country, two systems and its own legal boundaries since its return by the British to China in 1997. This means that although one country with China, Hong Kong will enjoy a high degree of autonomy, except in foreign affairs and defense for 50 years, to 2047. As a result, as a special region in China, Hong Kong became an autonomous country that was not completely free of China.

Hong Kong and China are indeed under test for a massive Hong Kong demonstration of a government plan which will uphold the extradition law or propose a new extradition bill. It is feared by some Hong Kong that the extradition bill will become a threat to the independent justice of Hong Kong and can be used to target people who oppose the Chinese government (Cnbcindonesia.com, 2019).

The demonstration of the countermeasures bill has been going on since the beginning of 2019. But the climax came

\begin{tabular}{ll} 
How to cite: & Rico. (2021) Hong Kong Public Social Communication Strategies in a Demonstration Against the \\
& Proposed Extradition Law, 2(3). \\
\hline E-ISSN: & $2721-5202$ \\
\hline Published by: & Ridwan Institute \\
\hline
\end{tabular}


in June 2019. The actions of protestants came to the world's attention because they used several methods to get the attention of the government in the form of demonstrations. Several methods adopted by protestants became a form of public message to the government. Several unique ways of doing this research focus on communication strategy theory.

\section{METHOD}

The method used must be accompanied by a reference; relevant modifications should be described. Data analysis procedures and techniques should be emphasized in the literature review article. The stages and analysis of the research should be described in detail.

\section{RESULTS AND DISCUSSION}

\section{The Demonstrastion in Hong Kong}

The issue started in February 2019 when the Hong Kong security bureau submitted a draft document that contained a motion to change the extradition law. The bill proposes a change of the extradition agreement of any known criminal caught in Hong Kong being extradited to China. Many Hong Kong people are opposed to this proposed amendment. The disapproval was expressed in the form of the first March 2019 (Republika.co.id, 2019).

Not only do the charges against the extradition bill, demonstrators' intelligence against Chinese police and high technology are of enough concern to the world. They have self-mobilisation and technological capabilities, showing strong alignment without any leading (Lee, 2014). The use of masks and umbrellas by protesters evidently also served a special purpose. Both tools were used as conventional ways of avoiding the Chinese facial recognition system (JPNN, August 17, 2019). The high number of demonstrators has led the Hong Kong police to use face-recognition technology on the phone which is development in China to acquire the identity of the demonstrators as provocatators or anarchists. Not to be left out, protesters ran a counter using laser beams from the pointer aimed at the police apparatus. Laser light not only confuses police but also avoids crowd surveillance by using facial recognition technology (jawapost, August 16, 2019).

Interestingly, demonstrators are said to be moving without a structured group leader. Protesters in Hong Kong plan their actions through a decentralized organizational structure. Protesters rely on mail delivery applications through telegrams that are believed to be safer to share information with one another because messages can be encrypted that are so difficult to hack and can have a group of tens of thousands of people (theconversation, June 14, 2019). Online maps are also used by protesters to help locate police (news., October 24, 2020).

More and more demonstrators use several tactics to launch their protests (Tirto.id, 2019). The first tactic used by Hong Kong demonstrators is to dismiss the leadership figure in their actions. This leaderless resistance tactic is commonly known as the leaderless resistance. The second tactic is the use of the encrypted and active message applications for various online media forums. In addition to encrypted message applications such as telecommunications, other features such as airdrop (found only on the iphone) can also be used to spread posters and banners, even to the point of targeting people, on the swift and unconnected future. Before the action is made, telecommunication protesters often warn one another to activate the airdrop. The third tactic takes place in the field. Protesters on the front lines commonly use sign language tactics to communicate certain things. For example to request that some needed equipment get to the front immediately. Eventually, the long, extended human chain will be shoulder to shoulder to carry the instrument or object in front.

The fourth tactic is to create a special team to neutralize or extinguish the tear gas. Teams of five to six take a slight position behind the front line. When tear gas is thrown by the police, they will soon shut it down with a special equipment, a traffic cone to restrict its spread, and extinguish it by pouring water into the chimney. Fifth tactic, Hong Kong demonstrators will avoid clashes with 
authorities to prevent victims from coming out of sight without heavy equipment or urban battle tactics by being as orderly and undisciplined as they can be. "Onetwo" of satan's villains will signal the "onetwo" before it is followed by the next line behind them. The sixth tactic used was to open a cash donation to make a full-page $A D$ in the world's advance newspapers. The momentum target was the g-20 summit held in Osaka, Japan, late June 2019. The collection was successful.

\section{Communication Strategy}

According to (Wardani, 2017) strategy management processes can be seen in three stages, namely formulating strategy, implementing strategy, and evaluating strategy. Communication strategies are almost like communication planning guides and communication management to achieve a set goal. Arifin anwar 1984 (Sudarman, 2018) states that the elements that must be noted in formulating communication strategies are public introduction, messages, methods, media, and communicator. According to 2009 series (Sudarman, 2018) strategy is a means to an end. Communication strategy is how to conduct communication operations successfully. Communication alone has meaning as the transmission of one's thoughts or feelings (communicator) to another (communion). The thought may consist of ideas, information and opinion while feelings can be confidence, certainty, doubt, anxiety, anger, and courage (Koeswara \& Budianto, 2011).

The meaning of onong uchjana effendi's "communications dimensions" implies that communication strategies are a guide from communication and management planning to achieve a goal. To achieve that goal communication strategies must be able to demonstrate how tactical operation must be done, in the sense of the word that approaches can vary at times depending on the circumstances and conditions (Effendy, 1990).

The use of communication strategies (Smith, 2005:67), among other things: a plan, a deliberate course of action. B. a specific maneuver intended to distract the opponent or the competitor. A pattern, in a series of actions. A position, a way of putting the organization in a neighborhood. E. a perspective, an integrated way of winning the world. Whereas the purpose of the pace and faules (1994:344) strategy of communication (1994:344) is: a.to secure understanding, making sure that there is understanding in communication. B. to established, how well that admissions are maintained. C. to motive action, driven for motivation. D. The goals which the communicator, to achieve, how to achieve the goals the communicator seeks to achieve from the communication process. A cancellation of an extracurricular bill in Hong Kong.

R. Wayne pace, brent d ptaerson, and $\mathrm{m}$. Dallas burnet in his book technicalfor effective communication states that the central purpose of communication strategy is three things: to secure understanding, to established aceptance, and to affirmative action. To secure understanding means ensuring that communion understands with the message it receives. When communities receive or understand, the recipient must be built up (to quickenance) and eventually communication activities are motivated (to affirmative action).

3. Social Communication Strategy at Hong Kong Demonstration

The chaos in mainland China from mid-2019 to early 2020 is a reflection that the 'one country's two-system government's political system' is a grave challenge for the United Kingdom's post office of Hong Kong in July 1, 1997, where China used the communism system while Hong Kong used the system liberalism. The power of Hong Kong's understanding of freedom causes the region to be very sensitive in some issues, one of which is consequence law "Hong Kong killings carried out in Taiwan" (Sucitawathi, 2020).

Demonstrations highlight the high stakes of the 2019 Hong Kong government, with the major requirement being the retraction of the extradition bill. Several demonstrators in order to deliver messages against government policy have contributed to the world's spotlight. Protesters as communicators carry messages of thought and feeling to governments as communes. 
Demonstrations can be referred to as a communication process. In principle, communication would be done with several operational steps toward achieving a goal or what might be called a communication strategy.

Communication strategies are planning, planning and management to achieve goals. But to achieve that goal, the strategy does not serve as a road map indicating only direction but rather has to point out how its operational tactics (effendy in arumsari, 2020). Communication planning expert, Middleton, defines communication strategy as the best combination of all communication elements from communicator, message, conduit (media) receiver, to influence (effect) designed to achieve optimum communication purposes (Cangara, 2013). Communicators are, in this case, demonstrators who carry messages of demands through channels or media, providing a way to influence several action plans to bring new policies to governments as recipients of messages or communiques. Some of the ways that demonstrators' messages are delivered have been focused on the research.

The first operational tactic of the Hong Kong protest strategy is to eliminate the leader figure in action. This leaderless resistance tactic is commonly known as the leaderless resistance (Tirto.id, 2019). Protesters in Hong Kong plan their actions through a decentralized organizational structure. Protesters rely on mail delivery applications through telegrams that are believed to be safer to share information with one another because messages can be encrypted that are so difficult to hack and can have a group of tens of thousands of people (theconversation, June 14, 2019). Online maps are also used by protesters to help locate police (news., October 24, 2020). Planning and planning are by willingly sharing information both directly and indirectly so that the common aims of demands can be granted to the communities in this regard.

The second operational tactic in social communication strategies is the use of encrypted and active message applications in online media forums. Other than an encrypted message application like a telegram. Telegrams were selected because of the feel - safe features of interested hackers. In general, such openair media use as twitter can be one of the latest sources of information. The use of a hashtag on a twitter application will make it easier to present clear and current information about events at the crash site (Wetzstein, 2017). Online use of social media has been proven to relate significantly to public discourse and civic engagement (Ye et al., 2017). However, according to data, there was an increase in the quantity of mayybetween out of 5,503 cases of may-attacks in 2006 and then to 42,887 in 2011 . The number of cases has reached $680 \%$ (wilshusen, gegory c., 2014). This is what caused the demonstrators not to want to do a demonstration while using social media against their will.

In addition to telecommunications, such features as airdrop (found only on the iphone) are also used to spread posters and banners, even to the point of targeting people, on the swift and wireless (offline) next action. Before the action is made, telecommunication protesters often warn one another to activate the airdrop. A mutual reminder to power the airdrop includes planning to achieve a common goal of not falling behind updates on the ground.

Operational tactics in the third demonstrators' social communication strategies took place in the field. Demonstrators on the line are using sign language tactics to communicate certain matters. For example, when requesting some needed equipment immediately up to the front. Demonstrators will then stand shoulder to shoulder carrying the intended instrument or item from the back to the front (tirto. Id, 2019. Planning (planning) by making signs or signs with the intent of giving or receiving needed assistance from demonstrators.

The fourth tactic of social communication strategy is to create a special team that ACTS to neutralize or eliminate the tear gas. Teams of five to six take a slight position behind the front line. When tear gas is thrown off the police, they will soon cover it with a special equipment, a traffic cone, to restrict its 
smoke smoke, and extinguish it by pouring water into the chimney. Planning or planning by demonstrators on these tactics are planning to prepare the equipment before battle in the field. Demonstrators would be preparing devices such as water, special desserts and traffic cones on the road. The purpose of the action was a tear gas that could impede the march of protests could be avoided.

The fifth tactic of social communication strategy is to avoid clashes. Planning or planning have been done in such a way by demonstrating in orderly and disciplined fashion. This small percentage of demonstrators have less than local law enforcement equipment.

The next communication strategy was the opening of a fund donation to a fullpage $A D$ payment on the most familiar magazines in the world. Planning has been done by opening a donation with a view to potential potential magazines to open a new outlook for the world community. Planning to collect the fund successfully leads to a goal where Hong Kong's demontran message "stand with Hong Kong at g20" ran in the New York times, the guardian, le monde, the Australian, asashi shim bun, globe \& mail, to Seoul daily.

The demonstrators' tactics are a form of Hong Kong protest that can be categorized as a government group. Conflict according to the coser (Wang \& Yotsumoto, 2019) can have such positive effects as the birth of new rules, norms, and institutions that function as socialization agents for both competitive parties. This was what the demonstrators expected, even if it did.

\section{CONCLUSION}

The demonstration will be done to achieve the desired goal. Some measures have been taken to get the message across without causing harm to the parties. Several unique strategies of Hong Kong's demonstrations have been carried out to maintain a message to be delivered by another group of Hong Kong governments. Demonstrations continue to be made to fight for the five things of the Hong Kong government, removing the extradition bill completely, calling "rioting" to demonstrators, lifting criminal charges against demonstrators, conducting extensive investigations into police ACTS of violence, and breaking the pro-china congress legislation and implementing public-based universal or democrat.

\section{REFERENCES}

Cangara, H. (2013). Perencanaan dan strategi komunikasi. Jakarta: Raja Grafindo Persada. Google Scholar

Cnbcindonesia.com. (2019). Anti Pemerintah, Ribuan Guru Hong Kong Masuk Barisan Demo. Cnbcindonesia.Com. Google Scholar

Effendy, O. U. (1990). IImu komunikasi teori dan praktek. Remaja Rosdakarya. Google Scholar

Koeswara, S., \& Budianto, H. (2011). Pengaruh Lingkungan Kerja dan Disiplin Kerja terhadap Kinerja Karyawan Packindo Farma Utama Jakarta. Jurnal Pasti, 4(2), 27-34. Google Scholar

Lee, F. L. F. (2014). Triggering the protest paradigm: Examining factors affecting news coverage of protests. International Journal of Communication, 8, 22. Google Scholar

Republika.co.id. (2019). Demonstrasi Hong Kong Lumpuhkan Bisnis dan Trasnportasi. Republika.Co.Id. https://www.republika.co.id/berita/inter nasional/ asia/19/07/03/pu23nq382Google Scholar

Sucitawathi, I. G. A. A. (2020). The HongKong China Government's Democratic Insability in terms of the Political Realism Perspective. Journal of Etika Demonstrasi. Google Scholar

Sudarman, A. (2018). Strategi Komunikasi untuk Meningkatkan Kesadaran Masyarakat dalam Membayar Zakat Maal. Communicatus: Jurnal IImu Komunikasi, 2(1), 39-58. Google Scholar

Tirto.id. (2019). "Strategi Demo Hong Kong 
hingga Pemerintahan Batalkan RUU Ekstradisi". Tirto.Id.

https://tirto.id/strategi-demo-hongkong-hingga-pemerintah-batalkan-ruuekstradisi-eiJs Google Scholar

Wang, L., \& Yotsumoto, Y. (2019). Conflict in tourism development in rural China. Tourism Management, 70, 188-200. Google Scholar

Wardani, R. W. K. (2017). Strategi Komunikasi Badan Amil Zakat Nasional dalam Pengumpulan Zakat Maal. IImu Dakwah: Academic Journal for Homiletic
Studies, 11(1), 151-176. Google Scholar

Wetzstein, I. (2017). The visual discourse of protest movements on Twitter: The case of Hong Kong 2014. Media and Communication, 5(4), 26-36. Google Scholar

Ye, Y., Xu, P., \& Zhang, M. (2017). Social media, public discourse and civic engagement in modern China. Telematics and Informatics, 34(3), 705714. Google Scholar

\section{Copyright holder:}

Rico, Siti Fatimah and Muzahid Akbar Hayat (2021)

First publication right:

Journal of Social Science (JSS)

This article is licensed under:

(c) $6{ }_{\mathrm{BY}}$ (อ) 